\title{
Hubungan Mobilisasi Dini dengan Proses Penyembuhan Luka pada Pasien Pasca Laparatomi di Bangsal Bedah Pria dan Wanita RSUP Dr. M. Djamil Padang
}

\author{
Wira Ditya ${ }^{1}$, Asril $^{Z^{2}}$ ahari ${ }^{2}$, Afriwardi $^{3}$
}

\begin{abstract}
Abstrak
Mobilisasi dini merupakan kebijakan untuk secepat mungkin membimbing penderita turun dari tempat tidur dan berjalan. Tatalaksana ini adalah salah satu faktor yang mempengaruhi penyembuhan luka pasca pembedahan serta dapat mengurangi risiko komplikasi. Tujuan penelitian ini adalah menentukan hubungan antara mobilisasi dini dengan proses penyembuhan luka pada pasien pasca laparatomi di bangsal bedah pria dan wanita RSUP Dr. M. Djamil Padang. Penelitian ini menggunakan rancangan cross sectional study dengan jumlah sampel 31 responden yang diambil secara consecutive sampling technique. Data dikumpulkan melalui kuesioner dan lembar observasi, kemudian dianalisis dengan uji chi-square dengan derajat kepercayaan 95\%. Hasil penelitian menunjukkan terdapat hubungan yang bermakna antara mobilisasi dini dan proses penyembuhan luka pasca laparatomi $(p=0,003)$. Pasien mobilisasi dini dengan penyembuhan luka yang baik sebanyak 14 responden (77,8\%) dan buruk 4 responden (22,2\%). Responden tanpa mobilisasi dini dengan penyembuhan luka yang baik berjumlah 3 responden (23,1\%), sedangkan yang buruk 10 responden (76,9\%). Berdasarkan hasil penelitian, dapat disimpulkan bahwa terdapat hubungan antara mobilisasi dini dengan proses penyembuhan luka pasien pasca laparatomi di bangsal bedah pria dan wanita RSUP Dr M. Djamil Padang.
\end{abstract}

Kata kunci: laparatomi, mobilisasi dini, proses penyembuhan luka

\begin{abstract}
Early mobilization is policy to guide the patients out of their bed to walk as soon as possible. Early mobilization is one of the factors that affect post surgical wound healing and may reduce the risk of complications. The objective of this study was to determine the relationship between early mobilization and wound healing process for post laparatomy patients in men and women surgical ward of Dr. M. Djamil General Hospital Padang. The design of this study was a cross sectional to 31 respondents by consecutive sampling technique. Data were collected through questionnaire and observation, then analyzed by chi-square test with 95\% confidence interval. The results show there was a significant relationship between early mobilization and wound healing process $(p=0.003)$. Patients of early mobilization with good wound healing were as many as 14 respondents (77,8\%) and bad as many as 4 respondents (22,2\%). Respondents without early mobilization who are in good wound healing were 3 respondents (23,1\%) while bad ones are 10 respondents (76,9\%). Based on the results of the study, it can be concluded that there is a relationship between early mobilization and wound healing process for post laparatomy patients in men and women surgical ward of Dr. M. Djamil General Hospital Padang.
\end{abstract}

Keywords: laparatomy, early mobilization, wound healing process

Affiliasi penulis: 1. Prodi Profesi Dokter FK UNAND (Fakultas Kedokteran Universitas Andalas Padang) 2. Bagian Bedah FK UNAND, 3. Bagian Fisiologi FK UNAND
Korespondensi: Wira Ditya, Email: wiraditya220492@gmail.com, Telp: 085766083065 


\section{PENDAHULUAN}

Pembedahan atau operasi adalah segala tindakan pengobatan yang menggunakan cara invasif dengan membuka atau menampilkan bagian tubuh yang akan ditangani, umumnya dilakukan dengan membuat sayatan yang diakhiri dengan penutupan dan penjahitan luka. ${ }^{1}$ Pembedahan dilakukan karena beberapa alasan, seperti diagnostik (biopsi, laparatomi eksplorasi), kuratif (eksisi massa tumor, pengangkatan apendiks yang mengalami inflamasi), reparatif (memperbaiki luka multipel), rekonstruksi dan paliatif. ${ }^{2}$

Laparatomi merupakan salah satu prosedur pembedahan mayor, dengan melakukan penyayatan pada lapisan-lapisan dinding abdomen untuk mendapatkan bagian organ abdomen yang mengalami masalah (perdarahan, perforasi, kanker, dan obstruksi). ${ }^{1} \quad$ Tindakan laparatomi dapat dilakukan dengan beberapa arah sayatan: (1) median untuk operasi perut luas, (2) paramedian (kanan) umpamanya untuk massa appendiks, (3) pararektal, (4) McBurney untuk appendektomi, (5) Pfannenstiel untuk operasi kandung kemih atau uterus, (6) transversal, (7) subkostal kanan umpamanya untuk kolesistektomi. $^{1,3}$

Data World Health Organization (WHO) yang dikutip oleh Haynes et al (2009) menunjukkan bahwa selama lebih dari satu abad, perawatan bedah telah menjadi komponen penting dari perawatan kesehatan di seluruh dunia. Diperkirakan setiap tahunnya terdapat 234 juta tindakan pembedahan yang dilakukan di seluruh dunia. ${ }^{4}$

Laporan Kiik (2013) menyebutkan adanya pengaruh mobilisasi dini terhadap waktu pemulihan peristaltik usus pada pasien pasca operasi obdomen. ${ }^{5}$

Berdasarkan Data Tabulasi Nasional Departemen Kesehatan Republik Indonesia Tahun 2009, tindakan pembedahan menempati urutan ke-11 dari 50 pertama pola penyakit di rumah sakit seIndonesia dengan 12,8\%, diperkirakan 32\% diantaranya merupakan tindakan laparatomi. ${ }^{6}$ Dari data rekam medis pasien RSUP Dr. M. Djamil Padang tahun 2010 diperoleh data rata-rata 30 pembedahan laparatomi dilakukan setiap bulannya pada tahun 2009. Hal tersebut menjadikan kasus pembedahan laparatomi menempati urutan ke-6 dari 40 pertama tindakan terbanyak yang dilakukan di RSUP Dr. M. Djamil Padang. ${ }^{7}$

Tindakan pembedahan yang dilakukan mengakibatkan timbulnya luka pada bagian tubuh pasien sehingga menimbulkan rasa nyeri. Nyeri dapat memperpanjang masa penyembuhan karena akan mengganggu kembalinya aktivitas pasien dan menjadi salah satu alasan pasien untuk tidak ingin bergerak atau melakukan mobilisasi dini. ${ }^{8}$ Pasien pasca operasi diharapkan dapat melakukan mobilisasi sesegera mungkin untuk mengurangi rasa nyeri yang dirasakan dan menurunkan insiden komplikasi pasca operasi. ${ }^{2}$

Mobilisasi dini dimaksudkan sebagai upaya untuk mempercepat penyembuhan dari suatu cedera atau penyakit tertentu yang telah merubah cara hidup yang normal. $^{2}$ Menurut Kasdu seperti yang dikutip oleh Rustianawati et al (2013), mobilisasi dini pasca laparatomi dapat dilakukan secara bertahap setelah operasi. Pada 6 jam pertama pasien harus tirah baring dahulu, namun pasien dapat melakukan mobilisasi dini dengan menggerakkan lengan atau tangan, memutar pergelangan kaki, mengangkat tumit, menegangkan otot betis, serta menekuk dan menggeser kaki. Setelah 6-10 jam, pasien diharuskan untuk dapat miring ke kiri dan ke kanan untuk mencegah trombosis dan tromboemboli. Setelah 24 jam pasien dianjurkan untuk dapat belajar duduk. Setelah pasien dapat duduk, dianjurkan untuk belajar berjalan. ${ }^{9}$

Beberapa tujuan dari mobilisasi antara lain: mempertahankan fungsi tubuh, memperlancar peredaran darah, membantu pernafasan menjadi lebih baik, mempertahankan tonus otot, memperlancar eliminasi alvi dan urin, mengembalikan aktivitas tertentu sehingga pasien dapat kembali normal atau dapat memenuhi kebutuhan gerak harian. ${ }^{10}$

Keberhasilan mobilisasi dini dalam mempercepat pemulihan pasca pembedahan telah dibuktikan dalam suatu penelitian terhadap pemulihan peristaltik usus pada pasien pasca pembedahan. ${ }^{11}$ Hasil penelitian tersebut adalah mobilisasi diperlukan bagi pasien pasca pembedahan untuk membantu mempercepat pemulihan usus dan mempercepat penyembuhan pasien. Pada penelitian tentang pengaruh mobilisasi dini pada 24 jam pertama setelah Total Knee Replacement (TKR) didapatkan hasil 
bahwa mobilisasi dini merupakan cara yang murah dan efektif untuk mengurangi timbulnya trombosis vena pada pasca operasi. $^{12}$ Trombosis vena merupakan salah satu komplikasi yang dapat terjadi pada pasca pembedahan akibat sirkulasi yang tidak lancar. ${ }^{2}$ Penelitian lain juga mengungkapkan bahwa latihan peningkatan kekuatan otot melalui mobilisasi merupakan metode yang efektif dalam pengembalian fungsi otot pada pasien pasca operasi. ${ }^{13}$ Mobilisasi yang dilakukan 2 jam pertama lebih efektif dilakukan dari pada 6 jam pasca pembedahan. ${ }^{14}$

\section{METODE}

Jenis penelitian ini adalah observasional analitik dengan desain cross-sectional study yang dilakukan di bangsal bedah pria dan wanita RSUP Dr.

M. Djamil Padang pada bulan September 2014 hingga Oktober 2014.

Populasi penelitian adalah semua pasien yang dilakukan tindakan laparatomi di RSUP Dr. M. Djamil Padang. Subjek yang dipilih adalah pasien pasca laparatomi di bangsal bedah pria dan wanita RSUP Dr. M. Djamil Padang yang memenuhi kriteria inklusi dan eksklusi. Kriteria inklusi adalah pasien laparatomi yang di rawat di bangsal bedah pria dan wanita RSUP Dr. M. Djamil Padang; pasien dengan anestesi umum; pasien dengan hemodinamik yang stabil; bersedia menjadi responden. Kriteria eksklusi adalah pasien laparatomi dengan komplikasi; pasien dengan status gizi yang buruk; pasien dengan penyakit diabetes mellitus; pasien yang pernah atau sedang mendapatkan terapi sitostatika. Subjek diambil dengan menggunakan metode consecutive sampling, dimana semua populasi yang memenuhi kriteria dijadikan subjek penelitian sampai jumlahnya mencukupi, yaitu sebanyak 31 responden.

Data dikumpulkan dengan kuesioner mobilisasi dini dengan 5 pertanyaan dan lembar observasi proses penyembuhan luka dengan 5 kategori.

Analisis data secara univariat dan bivariat menggunakan uji chi-square dengan derajat kepercayaan $95 \%$. Variabel dependen adalah proses penyembuhan luka, sedangkan variabel independen adalah mobilisasi dini.
HASIL

Responden yang dipilih adalah pasien pasca laparatomi di bangsal bedah pria dan wanita RSUP. Dr. M. Djamil.

Tabel 1. Distribusi responden berdasarkan jenis kelamin, usia, dan tingkat pendidikan

\begin{tabular}{lcc}
\hline \multicolumn{1}{c}{ Karakteristik } & $\mathbf{f}$ & $\%$ \\
\hline Jenis Kelamin & 18 & 58,1 \\
Laki-laki & 13 & 41,9 \\
Perempuan & 3 & \\
\hline Usia & 14 & 9,7 \\
$<20$ tahun & 45,1 \\
$20-40$ tahun & 10 & 32,3 \\
$41-65$ tahun & 4 & 12,9 \\
$>65$ tahun & 3 & \\
\hline Tingkat Pendidikan & 9 & 9,7 \\
Tidak Sekolah & 10 & 29,0 \\
SD & 6 & 32,3 \\
SMP & 3 & 19,3 \\
SMA & & 9,7 \\
Perguruan Tinggi & &
\end{tabular}

Tabel 1 menunjukkan bahwa frekuensi kelompok responden terbanyak pasca laparatomi adalah kelompok responden berjenis kelamin laki-laki yaitu sebanyak 18 orang $(58,1 \%)$, sedangkan perempuan sebanyak 13 orang $(41,9 \%)$.

Frekuensi kelompok responden terbanyak berdasarkan usia adalah kelompok usia 20 - 40 tahun, yaitu berjumlah 14 orang $(45,1 \%)$, diikuti kelompok usia 41 - 65 tahun sebanyak 10 orang $(32,3 \%)$ dan kelompok > 65 tahun yang berjumlah 4 orang (12,9\%), sedangkan kelompok usia yang paling sedikit adalah < 20 tahun yang berjumlah 3 orang $(9,7 \%)$.

Berdasarkan tingkat pendidikan, frekuensi responden terbanyak adalah kelompok berpendidikan SMP, yaitu sebanyak 10 orang (32,3\%). Kelompok dengan frekuensi kedua terbanyak adalah kelompok dengan tingkat pendidikan SD yang berjumlah 9 orang (29,0\%). Urutan ketiga adalah kelompok berpendidikan SMA sebanyak 6 orang (19,3\%), diikuti dengan kelompok dengan tingkat pendidikan perguruan tinggi dan tidak sekolah yang masingmasing sebanyak 3 orang $(9,7 \%)$. 
Tabel 2. Distribusi frekuensi mobilisasi dini pasien pasca laparatomi di bangsal bedah pria dan wanita RSUP Dr. M. Djamil Padang

\begin{tabular}{lcc}
\hline \multicolumn{1}{c}{ Mobilisasi Dini } & $\mathbf{f}$ & $\%$ \\
\hline Terlaksana & 18 & 58,1 \\
Tidak Terlaksana & 13 & 41,9 \\
\hline Jumlah & 31 & 100 \\
\hline
\end{tabular}

Berdasarkan Tabel 2 dapat dilihat bahwa responden yang melaksanakan mobilisasi dini lebih banyak dibandingkan dengan responden yang tidak melaksanakan mobilisasi dini, yaitu sebanyak 18 orang $(58,1 \%)$.

Tabel 3. Distribusi frekuensi proses penyembuhan luka pasien pasca laparatomi di bangsal bedah pria dan wanita RSUP Dr. M. Djamil Padang

\begin{tabular}{lcc}
\hline \multicolumn{1}{c}{$\begin{array}{c}\text { Proses Penyembuhan } \\
\text { Luka }\end{array}$} & $\mathbf{f}$ & $\%$ \\
\hline Baik & 17 & 54,8 \\
Tidak Baik & 14 & 45,2 \\
\hline Jumlah & 31 & 100 \\
\hline
\end{tabular}

Pada Tabel 3 menunjukkan bahwa proses yang baik pada penyembuhan luka responden lebih banyak dibandingkan dengan proses yang tidak baik pada penyembuhan luka responden, yaitu sebanyak 17 orang $(54,8 \%)$.

Tabel 4. Hubungan mobilisasi dini dengan proses penyembuhan luka pasca laparatomi

\begin{tabular}{|c|c|c|c|c|c|c|}
\hline \multicolumn{7}{|c|}{ Proses Penyembuhan } \\
\hline \multirow{3}{*}{$\begin{array}{c}\text { Mobilisasi } \\
\text { Dini }\end{array}$} & \multicolumn{4}{|c|}{ Luka } & \multicolumn{2}{|c|}{ Total } \\
\hline & \multicolumn{2}{|c|}{ Baik } & \multicolumn{2}{|c|}{ Tidak Baik } & & \\
\hline & $f$ & $\%$ & $f$ & $\%$ & $f$ & $\%$ \\
\hline Terlaksana & 14 & 77,8 & 4 & 22,2 & 18 & 100 \\
\hline $\begin{array}{l}\text { Tidak } \\
\text { terlaksana }\end{array}$ & 3 & 23,1 & 10 & 76,9 & 13 & 100 \\
\hline Jumlah & 17 & 54,8 & 14 & 45,2 & 31 & 100 \\
\hline
\end{tabular}

Berdasarkan Tabel 4 dapat dilihat proporsi responden yang melaksanakan mobilisasi dini lebih banyak dibandingkan dengan responden yang tidak melaksanakan mobilisasi dini. Pada hasil pengolahan data diatas, dapat dilihat bahwa $p=0,003$ ( nilai $p$ yang dianggap bermakna adalah $<0,05$ ), yang artinya terdapat hubungan yang bermakna antara mobilisasi dini dengan proses penyembuhan luka pasca laparatomi. Artinya, orang yang melaksanakan mobilisasi dini, proses penyembuhan lukanya akan lebih baik dibandingkan orang yang tidak melaksanakan mobilisasi dini.

\section{PEMBAHASAN}

Berdasarkan hasil penelitian, sebagian besar responden yang melaksanakan mobilisasi dini adalah pasien laki-laki berusia 20 - 40 tahun serta memiliki riwayat pendidikan SMP sebanyak 18 orang $(58,1 \%)$.

Jenis kelamin, tingkat pendidikan, serta usia mempengaruhi kemauan pasien untuk melakukan mobilisasi dini. ${ }^{15}$ Jenis kelamin dapat mempengaruhi respon nyeri dan mobilisasi dini. Biasanya pasien lakilaki lebih dapat menahan nyeri dari pada pasien perempuan, sehingga laki-laki lebih mampu melaksanakan mobilisasi dini. ${ }^{16}$

Berdasarkan penelitian Solikin pada tahun 2010 , diperoleh nilai $p=0,000$ untuk hubungan tingkat pendidikan dengan pelaksanaan mobilisasi dini pasien pasca bedah digestif di RSUD Ulin Banjarmasin. ${ }^{15}$ Tingkat pendidikan merupakan salah satu faktor yang mendukung peningkatan pengetahuan yang berhubungan dengan daya serap informasi, dimana orang yang memiliki pendidikan tinggi diasumsikan lebih mudah menyerap informasi. ${ }^{17}$

Salah satu faktor yang mempengaruhi seseorang dalam melakukan mobilisasi dini antara lain usia. $^{15}$ Orang dewasa cenderung tidak mau untuk menyusahkan orang lain dan berusaha semaksimal mungkin untuk melakukan apa pun sendiri. ${ }^{18}$

Berdasarkan data yang diperoleh menunjukan bahwa sebagian pasien pasca laparatomi mengalami proses penyembuhan luka yang baik. Salah satu hal yang mempengaruhinya adalah karena pasien melaksanakan mobilisasi dini. Ada beberapa pasien yang melaksanakan mobilisasi dini, tetapi proses penyembuhan lukanya tidak baik. Hal ini juga dipengaruhi oleh faktor lain, yaitu usia. ${ }^{18}$ Semakin tua seseorang, maka akan semakin lama dalam proses penyembuhan luka. Hal ini dipengaruhi oleh adanya penurunan elastin dalam kulit, perbedaan penggantian 
kolagen yang mempengaruhi penyembuhan luka, sehingga akan mempengaruhi lama perawatan pada pasien. $^{8}$

Hasil analisis bivariat menunjukkan dari seluruh responden yang berjumlah 31 orang, sebagian besar responden mengalami proses penyembuhan luka yang baik dengan mobilisasi dini terlaksana, yaitu sebanyak 14 orang $(82,4 \%)$ dan sebagian kecilnya adalah responden dengan mobilisasi dini tidak terlaksana yang mengalami proses peyembuhan luka yang baik, yaitu sebanyak 3 responden (17,6\%).

Nilai p sebesar 0,003 ini lebih kecil dari 0,05, sehingga dapat disimpulkan bahwa terdapat hubungan yang signifikan antara mobilisasi dini dengan proses penyembuhan luka pasca laparatomi.

Hasil tersebut sama dengan hasil penelitian yang dilakukan oleh Yusuf pada tahun 2013 tentang pengaruh mobilisasi dini terhadap proses penyembuhan luka post appendictomy di RSUD Prof. Dr. Aloei Saboe Kota Gorontalo Tahun 2013. Diperoleh $p=0,000$ yang berarti bahwa mobilisasi dini mempunyai pengaruh yang signifikan terhadap penyembuhan luka. Pada penelitian Yusuf ini, pasien dengan mobilisai dini yang kurang baik mempunyai kemungkinan 20 kali untuk mengalami luka tidak sembuh dibandingkan pasien dengan mobilisai dini yang baik $(R O=19,50) .{ }^{18}$ Mobilisasi dini dapat mempersingkat masa pemulihan untuk mencapai level kondisi seperti pra pembedahan. Hal ini tentu akan mengurangi waktu rawat inap di rumah sakit, menekan biaya perawatan, dan mengurangi stres psikis. ${ }^{19}$

Mobilisasi dini dapat menunjang proses penyembuhan luka pasien karena dengan menggerakkan anggota badan akan mencegah kekauan otot dan sendi, sehingga dapat mengurangi nyeri dan dapat memperlancar peredaran darah ke bagian yang mengalami perlukaan agar proses penyembuhan luka menjadi lebih cepat. $^{16} \mathrm{Hal}$ ini sejalan dengan pendapat Carpenito (2000) bahwa salah satu faktor yang mempengaruhi proses penyembuhan luka akibat pembedahan adalah mobilisasi dini. ${ }^{20}$ Mobilisasi merupakan faktor yang utama dalam mempercepat pemulihan dan mencegah terjadinya komplikasi pasca bedah. Mobilisasi sangat penting dalam percepatan hari rawat dan mengurangi risiko karena tirah baring lama, seperti terjadinya dekubitus, kekakuan atau penegangan otot-otot di seluruh tubuh, gangguan sirkulasi darah, gangguan pernapasan dan gangguan peristaltik maupun berkemih. $^{10,16}$

Wiyono dan Arifah pada tahun 2008 dalam penelitiannya tentang pemulihan peristaltik usus pada pasien pasca pembedahan mengatakan bahwa keberhasilan mobilisasi dini tidak hanya mempercepat proses pemulihan luka pasca pembedahan, namun juga mempercepat pemulihan peristaltik usus pada pasien pasca pembedahan. ${ }^{11}$ Dan mobilisasi yang dilakukan 2 jam pertama lebih efektif dilakukan dari pada 6 jam pasca pembedahan. ${ }^{14}$

Berdasarkan penelitian lain juga didapatkan bahwa pengaruh mobilisasi setelah pasca operasi laparatomi sangat besar manfaatnya dalam proses penyembuhan luka, karena mobilisasi dapat meningkatkan sirkulasi di daerah insisi sehingga akan meningkatkan transfortasi zat-zat esensial yang berperan dalam proses penyembuhan luka. ${ }^{8}$

\section{KESIMPULAN}

Terdapat hubungan antara mobilisasi dini dengan proses penyembuhan luka pasien pasca laparatomi di bangsal bedah pria dan wanita RSUP Dr. M. Djamil Padang.

\section{DAFTAR PUSTAKA}

1. Puruhito, Bisono. Pembedahan. Dalam: Sjamsuhidajat $R$, Wim de Jong, editor (penyunting). Buku ajar ilmu bedah. Jakarta: EGC; 2004. hlm 265-88.

2. Smeltzer SC, Brenda GB. Buku ajar Keperawatan Medikal Bedah. Edisi ke-8. Jakarta: EGC; 2001.

3. Burger JWA, Riet M, Jeekel J. Abdominal incisions: techniques and postoperative complications. Scandinavian Journal of Surgery.2002;(91):315-21.

4. Haynes AB, Thomas GW, William RB, Stuart RL, Abdel-Hadi SB, Dellinger EP, et al. A Surgical safety checklist to reduce morbidity and mortality in a global population. N Engl J Med. 2009;(360): 491-9. 
5. Kiik SM. Pengaruh mobilisasi dini terhadap waktu pemulihan peristaltik usus pada pasien pasca operasi obdomen di ruang ICU RSUD Labuang Baji Makassar. Jurnal Kesehatan. 2013;1(1):13-20.

6. Departemen Kesehatan RI. Riset kesehatan dasar. Jakarta: Departemen Kesehatan; 2010.

7. Fahmi F. Pengaruh terapi musik terhadap tingkat gangguan tidur pada pasien paska operasi laparatomi di IRNA B (Teratai) dan IRNA Ambun Pagi RSUP Dr. M. Djamil Padang (skripsi). Padang: Fakultas Keperawatan Universitas Andalas; 2012.

8. Noer NA. Faktor-faktor yang berhubungan dengan lama hari rawat pada pasien pasca operasi laparatomi di rumah sakit umum daerah Labuang Baji Makassar. 2010 (diunduh 26 September 2014). Tersedia dari: URL: HYPERLINK https://app.box.com/s/83103e737c60e4bb29c9

9. Rustianawati Y, Sri K, Rizka H. Efektivitas ambulasi dini terhadap penurunan intensitas nyeri pada pasien post operasi laparatomi di RSUD Kudus. JIKK. 2013;4(2):1-8.

10. Garrison SJ. Dasar-dasar terapi dan latihan fisik. Jakarta: Hypocrates; 2004.

11. Wiyono N, Arifah S. Pengaruh ambulasi dini terhadap pemulihan peristaltik usus pasien paska operasi fraktur femur dengan anestesi umum di RSUI Kustati Surakarta. Berita IImu Keperawatan, Journal News In Nursing. 2008;1(2): 57-62.

12. Chandrasekaran S, Ariaretnam SK, Tsung J, Dickison D. Early mobilization after total knee replacement reduces the incidence of deep venous thrombosis. ANZ Journal of Surgery. 2009; (79): 526-9.

13. Suetta C, Magnusson SP, Beyer N, Kjaer M. Effect of strength training on muscle function in elderly hospitalized patients. Scandinavian Journal of Medicine \& Science in Sports. 2007;(17):464-72.

14. Israfi J. Pengaruh mobilisasi dini latihan duduk terhadap peningkatan motilitas usus pada pasien pasca bedah dengan general anastesi di RSI Jemursari (skripsi). Surabaya: Fakultas Keperawatan Universitas Airlangga; 2010.

15. Solikin. Analisis faktor-faktor yang berhubungan dengan pelaksanaan mobilisasi dini pasien pasca bedah digestif di RSUD Ulin Banjarmasin. 2010. (diunduh 30 September 2014). Tersedia dari: URL: HYPERLINK

http://lib.ui.ac.id/file?file=digital/137230-\%2028480Analisis\%20faktor-full\%20text.pdf

16. Potter PA, Perry AG. Fundamental keperawatan. Edisi ke-4 (terjemahan). Jakarta: EGC; 2006. hlm 517-9.

17. Rismalia R. Gambaran pengetahuan dan perilaku pasien pasca operasi appendectomy tentang mobilisasi dini di RSUP Fatmawati Tahun 2009. (skripsi). Jakarta: Fakultas Kedokteran dan IImu Kesehatan Universitas Islam Negeri Syarif Hidayatullah; 2010.

18. Yusuf N. Analisis faktor-faktor yang mempengaruhi proses penyembuhan luka post appendictomy di rumah sakit umum daerah Prof. Dr. Aloei Saboe Kota Gorontalo Tahun 2013. 2013 (diunduh 25 September 2014). Tersedia dari: URL: HYPERLINK

http://kim.ung.ac.id/index.php/KIMFIKK/article/view File/2857/2833

19. Majid A, Judha M, Istianah U. Keperawatan perioperatif. Yogyakarta: Gosyen Publishing; 2011.

20. Carpenito LJ. Buku saku diagnosa keperawatan. Edisi ke-8. Jakarta: EGC; 2000. hlm 68-70. 